\title{
PRELIMINARY SURVEY OF EXOTIC INVASIVE PLANTS IN SOME WESTERN AND HIGH PLATEAU MOUNTAINS IN YEMEN
}

\author{
Arif Saeed Aqlan Alhammadi \\ Department of Biology, Faculty of Science, University of Sana'a, Sana'a, Yemen \\ Email: arifalhammadi@gmail.com
}

\begin{abstract}
:
Yemen is the richest country in the Arabian Peninsula in its biodiversity at all levels; genes, species, ecosystems and traditional knowledge. It is believed that the two serious threats to biodiversity are habitat destruction and nonnative species invasion in any ecosystem. Inspite of the observed threats of exotic invasive plant species in Yemen, these plants continue to be unchecked and unmonitored. The objective of this study is to provide information and accurate identification of the most abundant exotic invasive plant species. Pilot survey of these plant species was carried out mainly in mountainous areas which is the most fragile ecosystems. Interviews with local people for primary assessment of the invasive plant species impact were also made, in addition to primary field observations. The results indicated that new invasive plant species were recorded in the country, although they are very abundant at this time, Parthenium hysterophorus was recorded for the first time in hillsides in Hajah. Parthenium hysterophorus is sensitizer causes many health problems to human and animals, it also strong allelopathic weed. This weed in addition to the unpalatable and allelopathic Tagetes minuta has replaced native grazing vegetation in escarpment and the last has also invested the wastelands, roadsides, grazing lands, and abandoned fields even at above elevation of $3000 \mathrm{~m}$. Tagetes minuta has led to reduction in population of Acacia asak trees and other species in the invasion areas. Opuntia dillenii was found at Bura mountains at the core of the protected area, its very serious threat to biodiversity and it causes blindness to animals and human whom get in contact with it. Other species were moving from the valleys upward in way to Bura mountains like Prosopis sp., on the other hand, new invasive spices of Nicotiania glauca was recorded in mountains surrounding Sana'a city. The distribution of some of the most abundant invasive plant species and their observed impact will be presented in this paper.
\end{abstract}

\section{INTRODUCTION:}

Yemen is very diverse in topography and biodiversity. It is much richer in its floristic vegetation than surrounding countries, which are mostly characterized by desert plants. About 3700 species belonging to 140 families of plants have been recorded in Yemen. Among them about 400 species are endemic (Alkhulaidi and Mahdi 2000). An unknown number of exotic plants species have been introduced to Yemen, both deliberately and accidentally. Exotic invasive species are believed 
to be the second largest cause of biodiversity loss after habitat destruction (Schwartz et al., 1996), and its negative impact on native biodiversity has been well documented. Exotic invasive plants have been found to change the composition of native communities and been associated with reduced plant and insect diversity. This can also affect soil microbial and arthropod composition (Batten et al., 2006, Pritekel et al., 2006). Exotic invasive species threaten biodiversity and habitat quality by displacing native plants, forming dense stands that exclude natives, hybridizing with natives, thereby changing their genetics, and supporting other non-native organisms. Recently many countries, with the support of convention to biodiversity, have developed biosafety frameworks and built up their capacities to manage the expected potential hazard of genetically modified organisms. These efforts, in addition to the implementation of conventions like the International Plant Protection Convention (IPPC), which addresses problems of plant pests, are a beginning toward dealing with these problems. Meanwhile, the worldwide spread of exotic plants has not received proper attention in spite of its serious impact. This preliminary study was undertaken to survey the most harmful and widely spread exotic invasive plants in the western mountainous part of Yemen, and to carry out a preliminary assessment of their impact by field observation and interviewing local people.

\section{MATERIALS AND METHODS:}

Pilot surveys were done from November 2006 through November 2007, concentrating on the most prevalent exotic invasive plants in various environments such as wastelands, roadsides, grazing lands, and abandoned agricultural fields. A literature survey was made (Chaudhary, and Revri, 1983; Chaudhary, 1999; Miller, and Cope, 1996; Wood, 1997; Chaudhary, 2000; Chaudhary, 2001 a,b,c). Plants identification was based on these references, 2000).

Interviews with local people were carried out in addition to field observations for preliminary assessments of the impact of exotic invasive flowering plants. The study area was the western mountainous part of Yemen from Taiz in the South to Hajah in the North. Plant samples were kept in the authors' collection at the department of biology, faculty of Sciences, University of Sana'a.

\section{RESULTS AND DISCUSSION:}

Surveys in the western mountains included Jabal Sabeer, Jabal Bura', Jabal Nabi Shu'ayb, Alahjor and Tawilah. Sumarah, the northern western mountainous region of Hajah, Kohlan Afar Shares and Shalah Beer Ali were also surveyed. The surveys resulted in a listing of fifteen exotic invasive plants. These were only the most prevalent exotic invasive plants. These plants were clearly seen to be affecting human and animal health, biodiversity and agricultural ecosystems. The following are the plants having the most noticeable impacts. 
Parthenium hysterophorus L. (Asteraceae). Its common names are congress grass and rag weed and in Yemen, as a new plant it does not have a common name. It is native to the southern United States and Mexico, as well as to Central and South America. Observed effects of Parthenium hysterophorus L. to human health are skin irritation, runny nose and sneezing, and these symptoms were personally experienced by the author. Many cases of allergy due to consumption of honey from bees which feed on the flowers were reported in Hajah. Children, shepherds and farmers who have direct contact with this plant get dermatitis, nausea, giddiness and respiratory problems like asthma. The first record of this plant in the Arabian Peninsula was made in 1998 in Dhofar, Oman (Kilian et al., 2002). It is regarded as a weed of national significance in India and Australia. This study is the first report its presence in the western mountains of Yemen. Immediate action is needed from Yemen and Oman to eradicate Parthenium hysterophorus plants.

Tagetes minuta is a member of the Asteraceae family, native to South America. It is a noxious mountain weed in many countries, and is cultivated for its oil. In Yemen, it is displacing and reducing populations of native and several edible plants. Its flowers are not visited by honey bees, but other insects were observed foraging on its flowers. It also displaces plants preferred by honey bees. In the mountains where heavy and early invasion was seen, populations of native trees like Acacia asak are reduced and new generations have not been observed (Fig. 1). This weed is generally avoided by animals, but is rarely eaten by donkeys when no other plants are available for grazing. When forced to graze it, cows become dizzy and produce milk with an unpleasant smell and taste, which also affects the milk products. Published data indicate it is allelopathic to many plants (Alhammadi, 2008). This invasive species is expected to create new landscapes, and increase the incidence of dermatitis in humans. There is no known use of it in Yemen.

Lantana camara is of Central American origin and a member of a Verbenaceae. Its observed impacts include changes in land-cover, infestation cultivated land, field boundaries, pastures, rangelands, and waste places. In pastures it forms dense thickets which shade out and encroach upon desirable pasture plants. It forms pure stands over large areas rendering the land useless for pasture. It is especially insidious in the mountains of Ibb and Hajah. In Sana'a city it is cultivated as an ornamental. In valleys its dense thickets redirect runoff water causing soil erosion and flooding in agricultural lands. Some people eat its fruits, but no cases of poisoning have been reported. Small plants are spreading extensively around the cities of Sana'a , Hajah and Ibb.

Opuntia is member of the New World family Cactaceae. About four species were found in the study area. One, Opuntia ficus-indica $(L)$, is naturalized and used as a source of large edible orange-yellow fruit. This species is not invasive, and in Sana'a some farmers grow it as a crop. It is expected to be an alternative crop to grapes due to its drought resistance and the low input 
needed for its production and higher yield. Exportation of its fruits began two years ago. It is a medium to high altitude plant $(1500-3000$ m). The second species is Opuntia dillenii. It has a sour, prickly, pink unpalatable fruit. Some local people say it was deliberately introduced by the Imam of the previous ruling regime for ink making purposes. The plant occurs mostly at lower altitudes $(200-1200 \mathrm{~m})$ and at the core of the Jabal Bura' Protected Area. Although there was an eradication program just after the area was declared protected, this plant has already ascended to high altitudes, and it is an invasive plant in Sana'a and Raima, where it has become a devastating pest. It causes blindness to human and animals by small spine of its fruits. It is also changing ecosystems, by blocking natural water flow, and its dense thickets are excluding grazing animals (Fig. 2).

The other two species are probably hybrids. One of them is spreading in Sumarah Mountain in Ibb governorate. It has very dense and thick thorns. The last three species represent threats to the integrity of ecosystems and land-cover.

Prosopsis juliflora is native to Central and South America. It is a fast growing nitrogen fixing species tolerant to arid conditions and saline soils. It was deliberately introduced in the1970s to stabilize sand in Tihama. It is a coastal and low altitude plant, but is increasing its range upward towards the Jabal Bura' protected area. A few plants were also seen in Sana'a city and in Thamar at elevations above $2000 \mathrm{~m}$. It is a serious invasive plant in United Arab Emirates, Oman, Saudi Arabia and Yemen (Miller, and Cope, 1996). It is used for construction, charcoal production, and recently the seeds were mixed with wheat to produce a very palatable human food. It is also forage for honey bees. Regional cooperation is needed to manage or eradicate this plant.

Nicotiana glauca is a South American species of the Solanaceae family. This species is acclimated to areas of warm-arid and warm semi arid climates, and to conditions of water deficit and high temperatures. According to Bogdanovic et al., (2006 and references therein) it also invades moist regions, beside roadsides and along riverbanks, and reaches altitudes up to $3000 \mathrm{~m}$. It is a cosmopolitan invasive species that represents a threat to the native flora. It has invaded Central America (Mexico, California, and Channel Islands), Africa (Morocco, South Africa and Namibia), Palestine, Australia, and Oceanic Islands. It is also widely naturalized in many parts of the European Mediterranean region (Spain, Portugal, France, Italy, Sicily, Corsica, Sardinia, Greece and Crete). As an invader it occupies waste places, dry riverbeds, roadsides and riverbanks of warm temperate, arid and subtropical dry and moist climatic zones. $N$. glauca is invading semi-natural or natural habitats which are of conservation interest. This species was recently introduced to Yemen. To best of authors' knowledge it is not recorded in Yemen in any published literature, but has been recorded in neighboring Saudi Arabia. It occurs in and around Sana'a city (Fig. 3). It is not overly abundant, but is spreading very fast. Based on the above distribution, and owing to traits like high production of wind dispersed 
seeds, early reproductive maturity, a rapid rate of growth, grazing- and drought-resistance and tolerance to a wide range of environmental conditions (Bogdanovic et al., 2006), it is expected to become one of the most noxious weeds in the country. An eradication programme in coordination with the Saudi Arabian government is needed to prevent its uncontrolled spreading.

Verbesina encelioides is native to North and South America and is a member of Asteraceae family. Not previously reported in Yemen, it has been seen in the mountainous city of Taiz, and in the western part of Sana'a, city. It seems it was introduced as an ornamental plant because of its beautiful flowers. It is considered as weed in North India, and in Saudi Arabia it is very abundant and naturalized. It is reported to be able to survive under a wide range of climatic conditions including droughts and high temperatures. This species caused livestock death as a result of toxic compound named galegine the compound compromises respiretion, causes hemorrhaging of heart, and ultimately results in death (Keeler et al., 1992)

Mirabilis jalapa, Argemone ochroleuca, (Fig.4), Argemone mexican and Flaveria trinervia are also invasive plants which have become dominant at some localities. Their impact and spread are less than the above mentioned species. Bidens aurea is also expected to be an invasive plant in Yemen. Its cultivated and named green tea and used as tea, It belong to Asteraceae family and it is reproduced vegetatively and by seeds. It has also shown strong drought resistance.

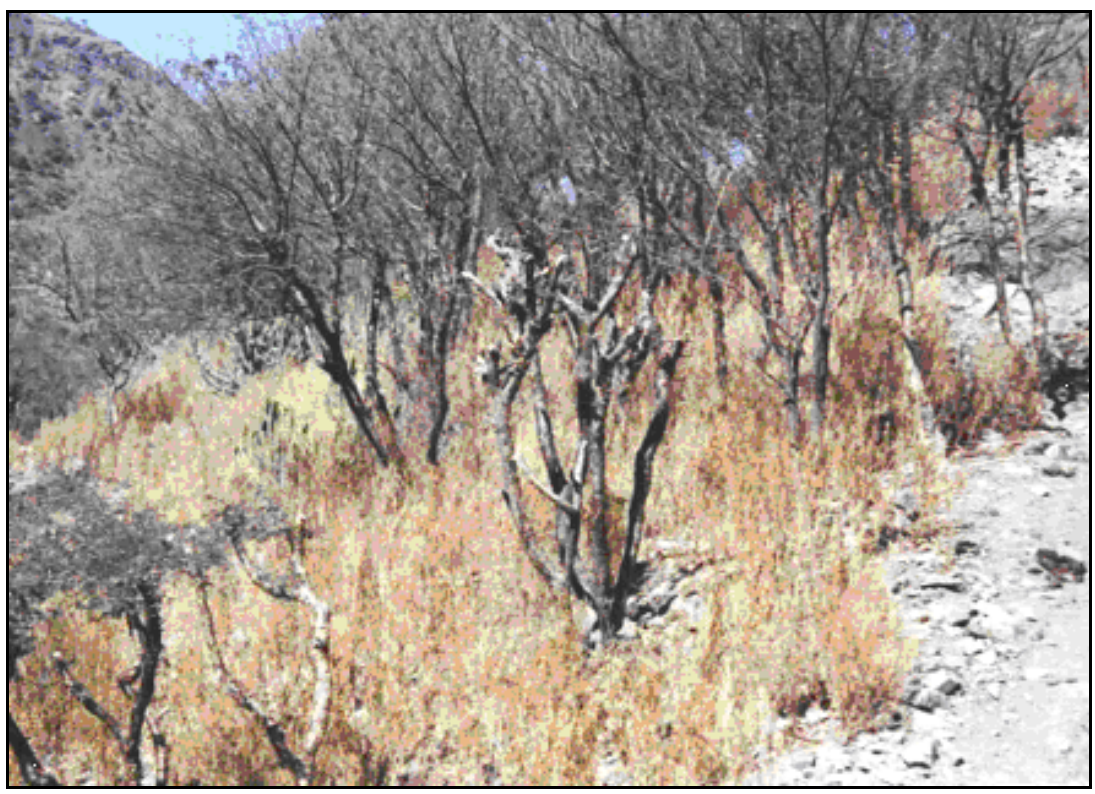


Fig. 1: Invasion by Tagetes minuta in Acacia asak rangelands. Note the lack of young Acacia asak plants or seedlings to substitute the dry dead Acacia plants. Note also the complete lack of other species. This type of rangeland was used for grazing prior to the invasion

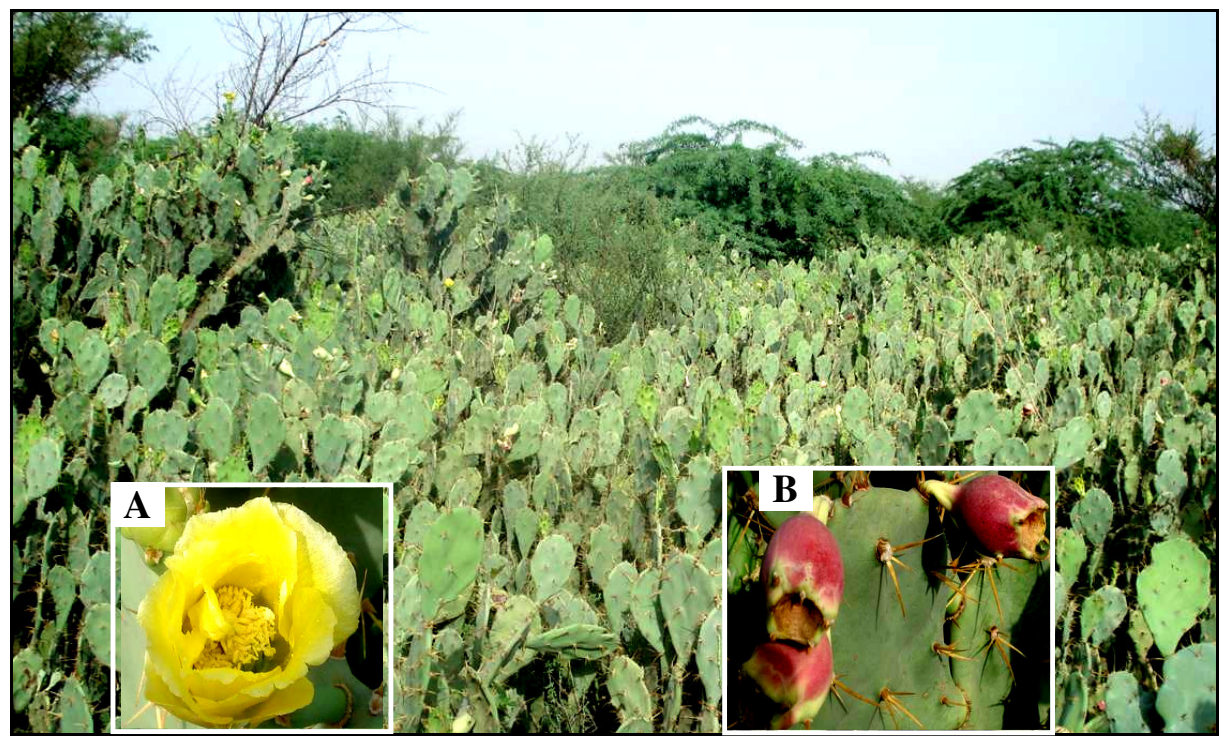

Fig. 2 : Invasion by Opuntia dillenii (Ker-Gawel.) at lower altitudes, Note how it is dense, the invasion results in blocking water and animals ways. Its flowers (A) and fruits (B) are shown.

\section{At the back Prosopsis juliflora can be seen.}
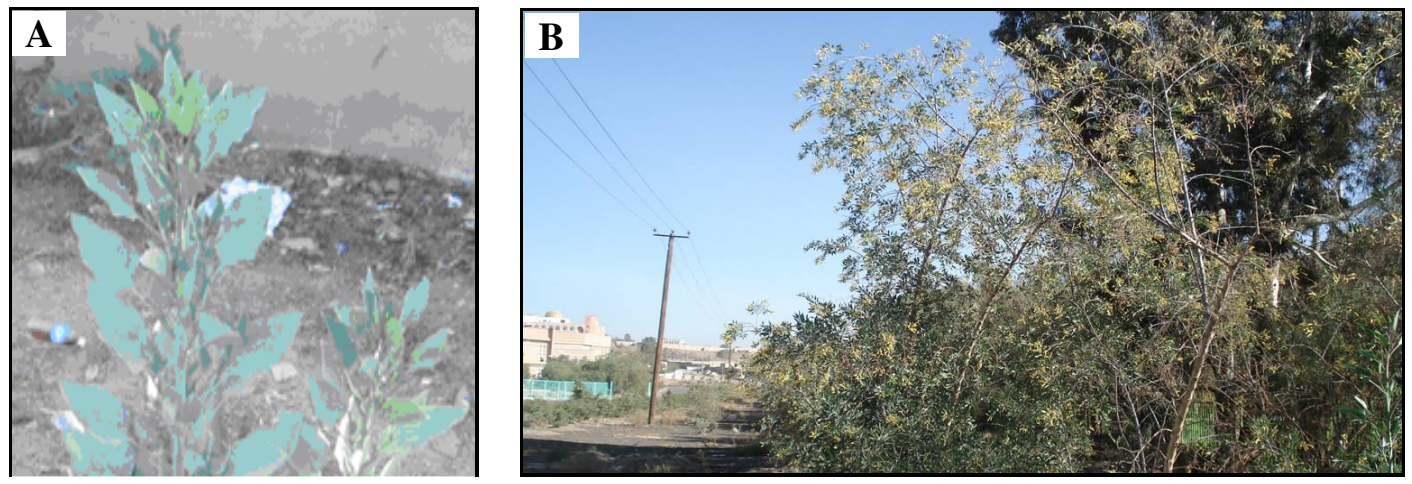


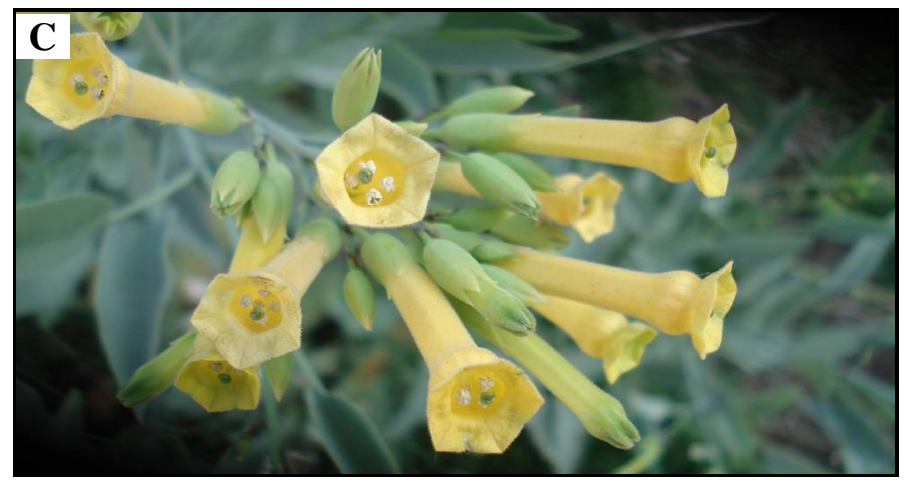

Fig. 3: Nicotiana glauca, young vigorous plant (A), anther mature full of flowers plant (B) and flowers (C)

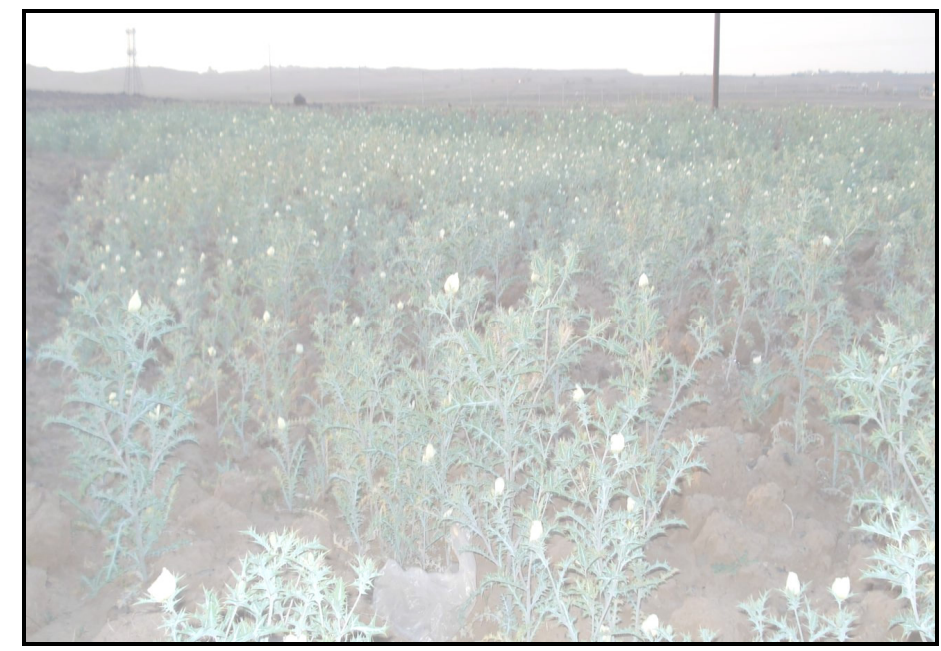

Fig. 4: Invasion of abandoned agricultural fields by Argemone ochroleuca

\section{RECOMMENDATIONS:}

Standard survey methods for detection and monitoring of exotic invasive plants should be used (Huebner, 2007). A team consisting of plant taxonomists, ecologists, socio-economic specialists and rangeland biologists is needed to carry out a thorough study of this topic. Early detection and monitoring of newly arrived plants is necessary to prevent the introduction, establishment and spread invasive plants. Awareness in the local communities should be raised concerning the consequences of invasive plants on ecosystems services, their mode of introduction and the importance of not burning imported foods or grains contaminants or dropping contaminated materials near to houses and farms. Clear and convincing information on the environmental and socioeconomic impact of invasive plant species must be provided to the public and officials. Remote sensing should be used to explore the spread of the most common and most aggressive invasive plants. Regional 
and international management is needed for the success of invasive plant programs.

\section{Acknowledgements:}

I am thankful to the American Institute for Yemeni Studies for partial financial support to carry out the field trips for collection of plants samples and for literature for identification of exotic invasive plants. I am also indebted to Prof. Dr Abdulkareem Nasher and Dr Mansoor Althobhni, for their help in identification of some plants. 


\section{REFERENCES:}

Alhammadi A. S. A.(2008): Allelopathic effect of

Tagetes minuta $\mathrm{L}$. water extracts on seeds germination and seedling root growth of Acacia asak. Assiut University Bulletin For Environmental Researches. 11:17-24.

Al-khulaidi, A. A. and Mahdi, A. (2000): Botanical Geography and Vegetation of Yemen. Obadi center for studies and publishing, Sana'a, Yemen. (In Arabic).

Batten, K. M., Kate, M., Scow, K. F., Harrison, D. and Harrison, S.P.(2006): Two invasive plants alter soil microbial community composition in serpentine grasslands. Biological Invasions. 8, 217230.

Bogdanovic, S., Mitic, B. Ruscic, M., and Donina, K (2006): Nicotiana glauca Graham (Solanaceae), a new invasive plant in Croatia. Acta Bot. Croat 65, 203209.

Chaudhary, S.A. and Revri, R. (1983): Weeds of the north Yemen. Desutsche Gesellschaft Fur Technische Zusammenarbeit (GTZ) GmbH, Germany.

Chaudhary, S.A. (1999): Flora of the Kingdom of Saudia Arabia. V. (1). Ministry of Agriculture and Water, national Harbarium, National Agriculture and Water Research Center, Riyadh. Saudi Arabia.

Chaudhary, S.A (2000): Flora of the Kingdom of Saudia Arabia. V. (2), Part3. Ministry of Agricultural and water, national Herbarium, National Agriculture and
Water Research Center. Riyadh Saudi Arabia.

Chaudhary, S. A. (2001a): Flora of the Kingdom of Saudia Arabia. V. (2), Part1. Ministry of Agricultural and water, national Herbarium, National Agriculture and Water Research Center. Riyadh. Saudi Arabia.

Chaudhary, S. A. (2001b): Flora of the Kingdom of Saudia Arabia. V. (2), Part 2. Ministry of Agricultural and water, national Herbarium, National AgricuIture and Water Research Center. Riyadh Saudi Arabia.

Chaudhary, S. A. (2001c): Flora of the Kingdom of Saudia Arabia. V. (3). Ministry of Agricultural and water, national Herbarium, National Agriculture and Water Research Center. Riyadh. Saudi Arabia.

Huebner, C.D. (2007): Detection and monitoring of invasive exotic plant: A comparison of four sampling Methods. Northeastern Naturalist 14: 183-206

Keeler, R.F., D. C. Baker, and K.E. Panter (1992): Concentration of galegine in Verbesina encelioides and Galega officianalis and toxic and pathologic effects induced by the plants. J. Environ. Pthol. Toxicol. Oncol. 11: 11-17.

Kilian, N., Hein, P. and Hubaishan, M. (2002): New and noteworthy records for the flora of Yemen, chiefly of Hadhramout and AlMahra. Willdenowia 32, 239-269.

Miller, A.G. and Cope, T.A. (1996): Flora of the Arabian Peninsula and Socotra. V.(1) 
Edinburgh University Press. In associ.

Royal Botanic Garden. Edinburgh, Kew, U.K.

Pritekel, C, Whittemore-Olson, A, Snow, N, and Moore, J.C. (2006): Impacts from invasive plant species and their control on the plant community and belowground ecosystem at Rocky Mountain National Park, USA. Applied Soil Ecology. 32, 132-141.

Schwartz M., Porter, D. Randall, J., and Lyons,

K. (1996): Impact of non-indigenous plants in Sierra Nevada Ecosystem Project: Final report to Congress, vol. II, Assessments and scientific basis for management options. Davis: University of California, Centers for Water and Wildland Resources www.ceres.ca.gov/ snep/pubs/web/PDF/VII_C47.PDF (downloaded on 1/2/2008).

Wood, J.R.I. (1997): A handbook of the Yemen, Flora. Royal Botanic gardens, kew, UK. 


$$
\begin{aligned}
& \text { مسح أولى للأنواع النباتية الدخيلة في بعض الجبال الغربية وجبال الهضبة العالية في } \\
& \text { البين } \\
& \text { عارف سعبد عقلان الحمادي } \\
& \text { قسم علوم الحياة - كلية العلوم - جامعة صنعاء - صنعاء - اليمن }
\end{aligned}
$$

اليمن أغنى دول الجزيرة العربية بتنوعها الحيوي على كل المستويات من الجينــات، والأتــواع، والأنظـــة

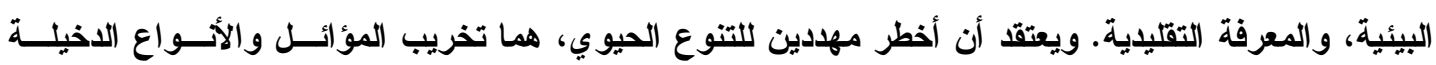

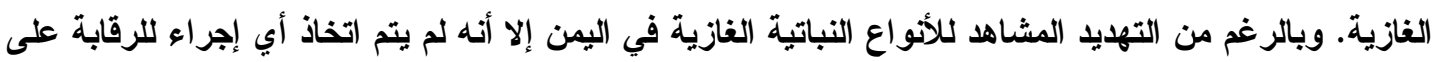
هذه الأنواع. تهذف هذه الدراسة إلى التعرف على الأنواع النباتية الغازية الاخيلة الأكثر انتشارا في اليمن. تم إجراء مسح

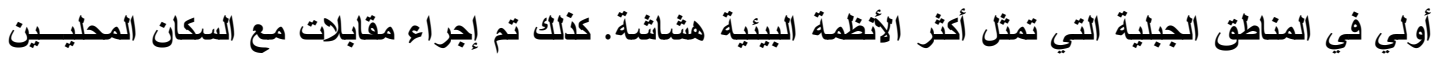

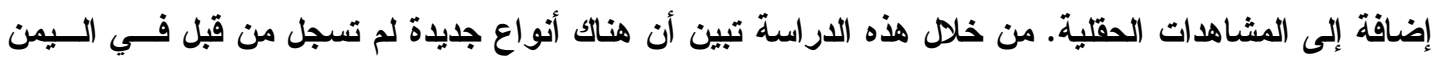

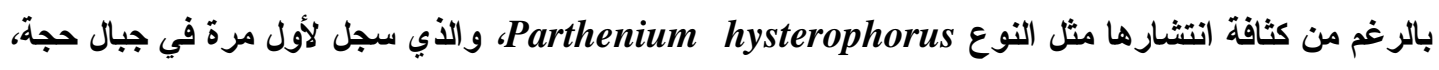

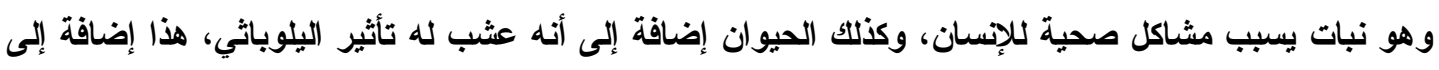

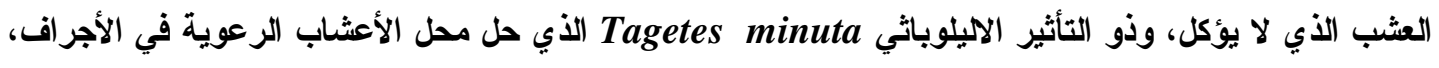

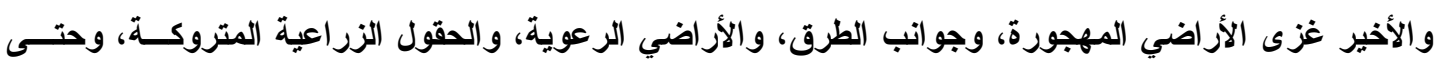

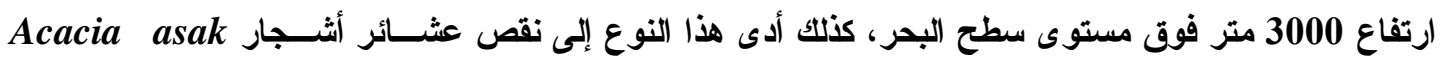

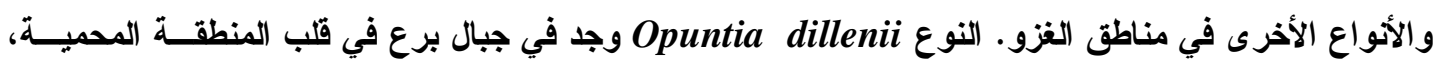

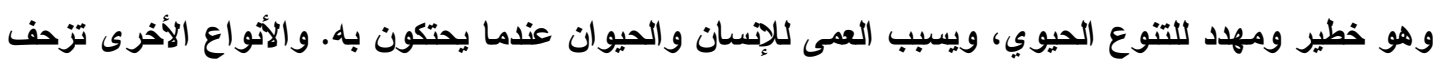

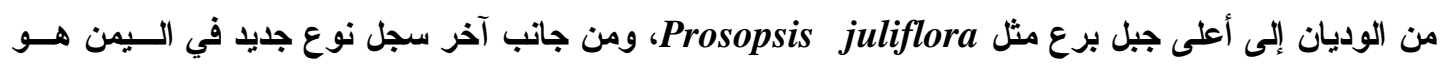
Nicotiana glauca 